Annual Proceedings of the Tall Timbers Fire Ecology Conference was dedicated to him in 1971, the first time that an individual had been honoured in this manner. The dedication of the proceedings, which dealt with fire in Africa, reads "The eleventh Tall Timbers Fire Ecology Conference is dedicated to Prof. John Phillips, University of Natal, Pietermaritzburg, South Africa, for his leadership and inspiration in the development of the 'holistic' approach to fire ecology in Africa. Prof. Phillips was certainly a true pioneer in this outlook of the ecosystem, which he combined with the experimental method almost half a century ago."

Much later, Phillips was to reminisce about his career as follows: "We knew very little about fire ecology in 1929, when I drafted, on a mountain massif at the edge of the Massai Steppe, Tanganyika, the paper later published in the South African Journal of Science in 1930." In the seven decades that have followed that drafting, the role and use of fire has of course been significantly clarified, in no small part due to the influence of Phillips' work and ideas.

\title{
FIRE: \\ ITS INFLUENCE ON BIOTIC COMMUNITIES AND PHYSICAL FACTORS IN SOUTH AND EAST AFRICA
}

\author{
John F.V. Phillips, D.Sc. (Edinburgh), F.R.S.E., F.L.S. \\ Deputy Director and Ecologist, Department of Tsetse Research, \\ Kondoa Irangi, Tanganyika Territory, Africa
}

Read 10 July 1930

\section{INTRODUCTION}

So far reaching in its influences, biological as well as economic, is the firing of vegetation in Southern and Eastern Africa, that it is not surprising that the subject should have received, during recent years, much attention of a general nature. While it is true that scientific workers have endeavoured to inform the public of the manifold evils following in the wake of fire, it is equally true that but little scientific experimentation has been brought to bear upon the problems connected with the periodic fires that sweep through such vast areas of Africa. In the present paper it is desired to outline, on the basis of present knowledge, some of the outstanding influences of fire, to bring together some of the more interesting references in the literature, and to emphasize the necessity of comprehensive, intensive research in the more important plant-and-animal formations.

\section{HISTORICAL OUTLINE}

From a consideration of probable geological and climatic cycles experienced in South and East Africa, it seems that periodic fires have swept the Grass and Tree-and-Grass Savannas down the ages, and that in suitable seasons fires have ravaged Evergreen Scrub and Forest communities since prehistoric times. While it is doubtless true that aboriginal man in his desire to protect himself against wild animals and in his hunting activities, fired vegetation, it is also safe to assume that lightning in many instances was responsible for commencing many fires. My observations in East Africa support this view, as do those of forest officers in parts of South Africa, while Clements (1916: 57) states that very numerous, destructive fires occur in Montana and Idaho during dry thunderstorms. 
According to Busse (1908), extensive firing of vegetation took place in East and Central Africa during the times of Hanno the Carthaginian. Sim (1907: 43) in an interesting chapter on forest destruction records that Vasco Da Gama, in 1497, on account of the smoke pall discernible from the sea, called the Cape "Terra de fume." It appears that firing was practised by the Hottentots, for Kolbe (1727) states that it was from these that the Europeans learned. At all events the various Placaats (No. 38 of Nov. 9, 1658; No. 71 of Dec. 16, 1661; No. 215 of Feb. 19, 1687) of the Dutch East India Company at the Cape, threatened punishment to those who fired grass. The last named Placaat went so far as to prescribe scourging for the first offence, and death as the penalty for the second. The Forest and Herbage Act of 1859, of the Cape of Good Hope, laid down relatively heavy penalties, for example, a fine not exceeding a $£ 100$, or imprisonment not exceeding 6 months or combined fine and imprisonment, but appears to have been applied all too rarely.

It is interesting to note that the Drought Investigation Commission (1926: 38) considers that fires are less prevalent in South Africa today than they were 75 years ago, owing to the absence of the tall grass of those days.

\section{THE INFLUENCES OF FIRE IN SOUTH AND EAST AFRICA}

Obviously the more important influences only, can be touched upon:

\section{Influences upon the Plant Succession and Animal Associates}

Elsewhere (J.F. Phillips 1930A) I have stressed the basic need of considering plants and animals as interdependent members of an integrated biotic community, hence, in my treatment of the vegetation I naturally include the animal associates. During several years' observation in Eastern Africa I have come to the conclusion that fire is a factor of the greatest importance in the life of biotic communities. While I definitely inclined to this view as the result of my investigations in South Africa, I must admit that it required the presence of the great fauna of the tropics of Africa to make me a convert. Nevertheless, I have little doubt that intensive work in South Africa, with its abundant smaller animals, would reveal important and interesting influences in plant-andanimal communities, directly or indirectly due to fire. At all events the principles probably would be found to be identical for South and East Africa.

\section{Upon Grassland and upon Communities Developing to Evergreen and to Deciduous Scrub Climaxes}

A consideration of the conditions obtaining in South and East Africa immediately suggests the division of Savanna into: (a) Climax Grassland, (b) Tree-and Grass Savanna of various types, all of which appear to develop, when undisturbed, to a Scrub climax, which in South Africa and at elevations above 5,000 feet in East Africa, is evergreen, while over the greater portion of East Africa, it is deciduous.

(a) In the Subtropical Bunch-grass Climax, which finds its best development in the Orange Free State, parts of the Transvaal, Basutoland, and parts of Southern Rhodesia, and in the mountain Grassland so well represented upon so many upland areas above 6,000 feet in Nyassaland, Tanganyika, Uganda and Kenya, fire shows effects depending entirely upon the type of grassland, the successional stage within such type, the season and intensity of firing, and the grazing management:

(i) Should the grassland be fired severely and frequently, the less xerophytic, more nutritious grasses decrease in abundance and dominance, 
yielding place to more xerophytic, less nutritious species. Thus, the relatively well covered Themeda-Andropogon grassland may yield to the more primitive, semi-open grassland chiefly constituted by species of Aristida, Eragrostis, Sporobolus. At the same time, grassland protected from fire for several years and then fired may deteriorate both in species and in density of cover.

(ii) Should the firing take place in late summer, the seeds are destroyed, young growth develops too early from the stimulated roots, and in areas of frost (South Africa and parts of Southern Rhodesia) is killed. Should the grassland be fired in winter, vernal aspect societies composed of shrubby Compositae, Asclepiads, Legumes, Malvaceae, Thymelaceae, Geraniaceae and bulbous Monocotyledons, develop; these take possession of the ground to the general detriment of the grasses, and, in many instances, are toxic to stock. Autumn firing, however, appears to produce effects the least detrimental either with reference to the density of cover of the grasses, or as regards the species.

(iii) Heavy grazing by domesticated or wild animals of young grass developing upon fired areas is conducive to sending the succession still nearer the pioneer, more xerophytic stages. Annual firing of Themeda-Andropogon communities, for example, under certain conditions, produces no retrogressive effects in the communities, provided grazing is either moderate or with-held, whereas these communities, when annually fired and subsequently heavily grazed, within a few years yield place to the Aristida-Eragrostis type of grassland. (iv) While continued, severe firing of Themeda-Andropogon and other communities of equivalent successional rank ultimately produces grassland of the more xerophytic, less valuable Aristida-Eragrostis type, the continued, severe firing of the Aristida-Eragrostis type in turn produces either very open, semi-desert conditions, or else a development of herbs, shrubs, and bulbous forms. These influences have been studied in South Africa by Bews (e.g., 1918), E.P. Phillips $(1920 A, B)$ and Staples (1926), while I have made observations upon them in East Africa. Actually the fringe only of the subject has been touched-more intensive as well as more extensive investigations are required - the Climax Grasslands being areas of high economic value.

(b) In grassland successional to either Evergreen or Deciduous Scrub, a condition very widely featured in South and East Africa, fire plays an important part in keeping the vegetation open. Without attempting to list even all the major vegetation types into which Tree-and-Grass Savanna successional to Scrub, may be divided, it is possible to get some impression of their diversity from the following great representative types:

(i) open grassland, with woody elements appearing;

(ii) Acacia spp. Open Woodland, the Acacias ranging from great trees like A. spirocarpa to such spreading, woody shrubs as A. Stuhlmannii;

(iii) Combretum-Terminalia-Other Spp. Open Woodland;

(iv) Berlinia-Brachystegia Woodland; 
(v) Deciduous Scrub with grassy glades......developing to climax Deciduous Scrub;

(vi) Evergreen Scrub with grassy glades......developing to climax Evergreen Scrub.

Within this seral Tree-and-Grass Savanna, fire unquestionably not only produces in the grasses the effects given under Climax Grassland, but, in addition, either entirely prohibits development of the climax stages, or else greatly retards the rate of succession. While it is true that many of the Acacias cast seeds that germinate all the more readily on a fire passing over them, it is just as true that the young seedlings - unless the circumstances be exceptionally favourable - cannot withstand the grass fires. From a consideration of the conditions holding within the Eastern Grassveld of South Africa, I feel that were fires excluded, development of Evergreen Scrub over very wide areas would be the outcome.

As regards East Africa, I am equally sure that fire has been the cause of the great Treeand-Grass Savannas being in their present, varying degree of "openness." 'The whole natural tendency appears to be toward the development of a Deciduous Scrub Climax of one type or another, but this tendency is at every turn thwarted by the annual and periodic fires. Busse (1908), Jaeger (1911), and Obst (1923) believe that much of the open grassland in East Africa simulating a climax community, has been produced by fire, a view to which Bews (1927: 111) appears to subscribe. Henkel (1928: 41) describes the persistent killing of young woody growth in "savannah forest" by fires.

\section{Upon the Macchia ("Fijnbosch"): Seral and Climax}

While there has appeared from time to time a deal of newspaper correspondence on the matter of firing vegetation in the Southwestern region of the Cape Province-more especially in the Cape Peninsula-actual scientific investigations of the influences of fire have been few.

Marloth (1924), Pillans (1924), Compton (1929) have drawn attention to the evil effects of fires in the Macchia, while Levyns (1922; $1924 ; 1929 A, B)$ has carried out some interesting intensive studies. During my ecological researches (1922-27) in the George-KnysnaHumansdorp region, I made general observations, and in addition investigated certain edaphic changes wrought in soils of the Macchia by fire (see p. 10). From the work of the above-mentioned writers, and from my own experiments it is possible to summarize the influences of fire as follows:

(i) Continued firing reduces the seldom abundant grass within Macchia areas, decreases the proportion of the more delicate, more nutritious, sub-shrubs and shrubs suitable for browse, but, increases the proportion and the luxuriance of largely useless Monocotyledonous plants-particularly Iridaceae, Liliaceae, Orchidaceae, and Restiaceae.

(ii) There is a definite tendency for the development of useless, often soil impoverishing shrubs, such as various species of Senecio, Stoebe, Helichrysum. According to Levyns (1929B) the dread Rhenosterbosch Elytropappus rhinocerotis is assisted to extend its territory by fires.

(iii) Even in the more favoured situations there is gradually a trend toward decreasing luxuriance, typical Macchia giving place to first a shorter, less luxuriant Macchia, then ultimately to a vegetation in which useless ruderals and equally useless invaders from the Karroo assume dominance. It is to be emphasized that not only is there thus aesthetically and scientifically 
a deterioration in the community, but also a very real loss in economic value. While Macchia even at its best cannot be considered good grazing or browsing, the deteriorated Macchia here referred to, is practically useless for these purposes. Furthermore, the chemical, physical, and biological conditions within the soil are much impaired - thus rendering the soil less valuable agriculturally.

\section{Upon Seral and Climax Subtropical and Tropical Evergreen Forest}

Diminution in area of subtropical and tropical forest in South and East Africa has been one of the major evil influences of fire. The more historical records are studied, and the more the testimony of existing plant-and-animal communities is attended to by the ecologist, the greater our knowledge of soil profiles becomes, and the more is it realized that in centuries past the areas of subtropical and tropical forest were considerably more extensive than they are today. Except in local instances during the period of European occupation, where excessive exploitation too has played a part, the agency responsible for this decrease is fire.

Let us first consider South Africa. It is commonplace to record that within the vicinity of Cape Town, extensive forests existed long after the landing of Van Riebeek. J.C. Brown (1887), for example, records a forest fire at Constantia that wrought $£ 10,000$ damages. Indeed, from passing references in records of travellers, from various relict forest patches within secluded areas, and from the nature of the vegetation of the intervening country, I consider it entirely possible that extensive areas of forest, seral and climax, existed between the Cape Peninsula and the present western limits - in the district of George - of the forests of the Midland Conservancy. That there was at any time an uninterrupted line of forest from near Humansdorp to Cape Town is un- likely, it being more probable that areas of forest alternated with areas of Macchia successional to forest. To-day forests within the region Cape Town-George-with the exception of an occasional larger patch such as that at Grootvadersbosch in the district of Swellendam, are practically non-existent. When we read in Fappe (1862) and Brown (1887) that fires annually ravaged the forests we are not surprised at this reduction. The forests of the George-Knysna-Humansdorp region are the most extensive in South Africa, but they, too, have been decreased appreciably by fire-we have only to study the excellent reports of Harison (1856-1888) to be convinced on this point. The great fire of February, 1869, which devastated thousands of acres of forest between George and Humansdorp, is said to have covered a total length of 400 miles and a width ranging from 15 to 150 miles. The smoke veiled the sun as far east as Sandflats, while ash fell in Uitenhage. As regards the forests of the Eastern Cape Province, it is all too plain from the reports of forest officers - notably Harison (1856-74), Hutchins (1884), C.C. Henkel (1889), Lister (1889), Harran (1898), and $\operatorname{Sim}(1900,1907)$ - that in the forests of Alexandria, the Katberg, the Pirie, the Amatolas, Fingoland, Pondoland, Tembuland and elsewhere in the Transkei, fire has played havoc even during the past half-century. Fourcade (1889) records great losses from fire in the forests of Natal.

On turning to East Africa we observe the same state of affairs Busse (1908), Siebenlist (1914) and others tell of extensive depletion in former German East Africa, while Hutchins (1909) and Troup (1922) record in no uncertain terms the heavy toll taken by fire in Kenya Colony. Troup (1922: 13) suggests that in the Juniperus procera. (so-called "Cedar") forests alone, the loss to the colony through fire has very greatly exceeded $£ 1,000,000$. My own views, based upon the study of soil profiles, the identification of charred portions of wood removed from the soil, and above all, observa- 
tion of the existing vegetation, are that fire has produced the following main effects in subtropical forest areas:

(i) Enormously decreased the area of climax forest and very greatly reduced that of the higher successional stages;

(ii) Produced over wide areas - for example between Cape Town and George, and in various parts of the George-Humansdorp region a subclimax of Macchia, (vide J.F. Phillips: 1926: 366, 1930B);

(iii) Produced over still wider areas - for example in the Eastern Cape Province, Natal, and upon the uplands of East Africasubclimaxes of seral Grassland, Tree-andGrass Savanna, and Evergreen Scrub.

In Tropical Forest areas of Eastern Africa it is evident that fire has been responsible for the following:

(i) Very considerable reduction in the extent of both seral and climax forest.

(ii) The forming of subclimaxes of

(a) Tropical Tree-and-Grass Savanna, the trees being largely evergreen, the grass luxuriant and attaining a height of 3 to 5 metres;

(b) Tropical Tall-Grass Savanna wherein woody growth is either entirely or almost absent - thus simulating the Climax Tall-Grass Savannas of moist areas of Tropical Africa;

(c) Tropical Evergreen Thicket, composed of a tangled mass of small trees, shrubs and lianes.

\section{Upon Karroid Vegetation}

Information as to the influences of firing the denser vegetation of parts of the Karroo, so far as I am aware, is extremely meagre. In view of the importance of proper veld management in the Karroo, this is a position that should be remedied as early as possible. I am unable to make any contribution to the subject based on personal studies other than ordinary general observation, but would suggest that illtimed firing, in conjunction with overgrazing, and in places removal of woody growth by the axe, is certain to induce deterioration in grazing and browsing, and to accelerate the process of soil erosion.

\section{Upon Growth-Forms in the Savannas}

In the great Tree-and-Grass Savannas of Eastern Africa fires sweep through year after year. Despite the vegetation being kept openthat is, in either a parklike or a woodland condition, free of dense growth-by these fires, the trees and large woody shrubs that manage to establish themselves, normally are little affected by the flames. Very young growth and older individuals showing either dead or dying portions naturally are killed in due course.

It has been suggested by Gibbs (1906), Busse (1908: 127), Bews (1925: 180, 1927: 74) and Henkel (1928: 51) that these fires may have an influence upon the development of some of the peculiar growth-forms existing in these regions. On the other hand, it is interesting to note that Volkens (1897: 266) considered that the growth-forms studied by himself in the Tree-and-Grass Savannas near Kilimanjaro, are in no sense attributable to the influences of fire, but would have been produced within these regions irrespective of this agent.

The growth-forms to which I am more especially alluding are:

(i) The grotesque orchard-like small trees and large woody shrubs as represented, for 
example, by Commiphora Fischeri, Lannea humilis, Gardenia Thunbergia, Dichrostachys glomerata, Dalbergia melanoxylon. These have been termed the Obstgartentypus (or orchard-tree-type) by Meyer (1892), and the Zwetschenbaumtypus (or plum-tree-type) by Busse (1906: 126).

(ii) The relatively succulent-and-woody small trees and shrubs so remarkably represented by the great genus Commiphora-for example Commiphora Schimperi, C. subsessilifolia and C. ugogensis.

(iii) The stunted, gnarled, relatively thinbarked woody shrubs of various genera, these frequently showing either extensive root-systems or else very large, thickbarked semi-subterranean stems.

(iv) The relatively thick-barked trees and shrubs of various genera. In connection with the thickness of bark it is of more than passing interest that a number of relatively thin-barked forms are highly fire-resistant; while this in part is due to highly active cambium, it would seem that there must in addition be some bio-chemical reason for the bark being either poorly inflammable or else possessed of remarkable resistance to high temperature.

(v) The coppice-like, large woody shrubsfor example, species of Grewia, Combretum, Bussea massaiensis - that show many stems to a single root-stock, and the wealth of coppice produced from the fired rootstocks of such trees Berlinia and Brachystegia spp.

From my own observations in East Africa it seems that in many species the killing of apical buds of stems and the main lateral buds, results in development of secondary lateral and adventitious buds, the outcome being the building up of an orchard-like tree or shrub form. Possibly where this has taken place down the ages, the form has become either partly or wholly fixed. That I am on dangerous ground in suggesting this I fully realize!

\section{Upon Animals Associated with the Vegetation}

Firing has become so natural a feature of the dry season in the Savanna regions of Africa that its influence upon animals associated with the vegetation is profound. I have space to refer briefly to a few of the more important influences only:

(i) Firing controls the movements of game herds, and the associated carnivores. The herds move before the fires, returning when the fresh shoots of the grasses appear. Where game is abundant - as in many portions of Tanganyika Territory - and where the fires sweep very extensive areas, these movements are on a grand scale.

(ii) Fire is responsible for a certain mortality in the young of animals, especially of ground-birds and smaller mammals, while it destroys eggs in large numbers. Where vegetation is especially dense, as on the fringes of forest and in ravines, it from time to time happens that even large mammals - for example, elephant, buffalo, large antelope - are killed by smoke or flame. There are some interesting references to the killing of elephant and buffalo, bushbuck and other animals in the George-Humansdorp region during the great fire of February, 1869.

(iii) Within forest and scrub regions where earthworms and various ground insects play an important role in soil aeration, fire does much harm by killing the more superficial organisms.

(iv) From investigations into the Tsetse-fly problem in East Africa, it seems that under 
suitable conditions of vegetation, season, and current aerial conditions, fires in the Tree-and-Grass Savannas act beneficially in that they either reduce or entirely destroy undergrowth and small thickets in which the Tsetse-flies (e.g., Glossina morsitans and G. swynnertoni) deposit their larvae. The larvae rapidly pupate. Should the vegetation cover be destroyed, not only are the puparial accumulations of many months destroyed, but also the breeding grounds for the future. Sander (1906) was the first to suggest the utility of fire in this connection, in German East African, while Swynnerton (1921) has developed the method considerably in the same country-now Tanganyika Territory.

(v) Although it has been suggested (e.g., Compton 1929: 3) that the killing of parasitic ticks by grass fires is a very temporary method of ridding the veld of these pests, my own observations go to support the view of Sander (1906) that fire is in many places an important agent of destruction.

\section{Influences Upon the Factors of the Habitat}

Although the general influences upon the countryside of excessive firing have been described in numerous popular and scientific papers, it nevertheless is true that actual experimental study of this subject of the first importance economically, has been sparse. Not only does this refer to South Africa, but also to other regions of the world where firing is widespread and frequent. Indeed, on looking through all available literature, I have been able to find references to actual quantitative work in the papers of Lieder (1897), Pardy (1906), Stead (1912), E.P. Phillips (1920A and $B$ ), Eden (1924), and J.F. Phillips (1930B) only. This is a position as remarkable as it is unsatisfactory, for I hold that before scientific workers lay down schemes for the employment or the control of fire in such countries as
South and East Africa, India, Australia, and America, it behoves them to have a much stronger array of data upon which to base their conclusions.

I attempt to outline what is known of the influences of fire upon certain soil and aerial factors. Unfortunately, information upon some of the dynamic properties in soils - for example, the water-supplying-power of the soil, oxygen-content, total chemical solutes readily available to plants - is wanting. It is to be remembered that factors are influenced differently, in instances, according to climatic zone, soil type, vegetation community, season of the year, and other circumstances.

(i) Humus, decomposed and raw, is destroyed or much reduced by firing. In the heavier soils of certain Macchia areas, of certain Subtropical and Tropical Forests, and in the periodically inundated sunklands ("mbuga," "dambo," "black-cotton-soil") of East Africa, reduction in humus is beneficial, but in the drier Macchia, most of the forest areas, and in the subtropical Grass and Tree-and-Grass Savannas, humus reduction or destruction acts detrimentally upon the properties of the soils. In the tropical savannas, where decomposition of organic matter is all too rapid, and but poor humus is formed, the destruction of organic matter probably has acted less detrimentally than is generally believed.

(ii) Where organic matter is present, firing results in a loss of nitrogenous matter, often with most serious consequences as regards fertility.

(iii) While firing does add appreciable amounts of potassium salts to the soil, it is in moister regions only that these produce good effects. In the drier regions the highly soluble salts are removed by leaching during the rains. In silty and clay soils the salts of potassium - for example, the car- 
bonate - and sodium carbonate injure the radicles of young plants, inhibit the development of nitrogen-fixing bacteria, and by producing "puddling," impair the aeration and drainage.

(iv) The $\mathrm{pH}$ of soils is appreciably altered by firing. Thus in the Macchia soils at Knysna, I (J.F. Phillips 1930B) found that after firing, the $\mathrm{pH}$ at 1 inch below the surface had decreased from $\mathrm{pH} 5.6$ to $\mathrm{pH}$ 5.4, while at 6 inches depth the change had been from $\mathrm{pH} 5.6$ to $\mathrm{pH}$ 6.5. As the plantand-animal succession develops, these differences gradually disappear. Eden (1924) working upon Harpenden Common found that the lime-requirement was appreciably greater upon burnt than upon unburnt soil. From investigations being conducted by my colleague, Mr. J.D. Scott and myself in East African Tree-and-Grass Savanna soils (residual and alluvial), it seems that changes in $\mathrm{pH}$ value are less marked than they are in Macchia and Forest soils in South Africa.

(v) The moisture-content and moisturesupplying-power of soils as influenced by firing require to be worked under varying conditions of climate, soil and vegetation. In evergreen vegetation-South African Macchia and Forest - I have found that firing, through destruction of much transpiring vegetation, actually tends to conserve the moisture values below about 6 inches, but the losses from the upper six inches are considerable. In Tree-and-Grass Savanna, however, firing during the dry season seems scarcely to alter the water-values at depths below 6 inches, as the grass stems and foliage are dry and non-transpiring. At depths above 6 inches the increased exposure of the soils to insolation and the evaporating power of the air, results in increased loss of moisture. E.P. Phillips (1920A) working in Climax Grassland at Pretoria, considers that firing actually increases the degree of absorption of moisture by the soil, but that this increased water-content is soon dissipated by the increased evaporation to which the naked soil is subjected. In Tree-and-Grass Savanna I have found the degree of "run-off" to be considerably greater upon fired sites than upon adjacent vegetation-clad ones. Where there has been an accumulation of fired debris, however, the fired soils certainly have absorbed more water than the non-fired. Determination of the water-supplying-power of fired and plant-clad soils of the same type is being conducted in Tree-and-Grass Savanna in East Africa by my colleague Mr. Scott and myself - in connection with the Tsetse-fly problem - the porous-porcelain soil points of Livingston being used.

(vi) Soil temperatures at the surface, just below the surface, and to a depth of several feet below the surface, are markedly influenced by firing. Surface temperatures during the day may be $100 \%$ higher upon fired soil than upon non-fired, plant-clad, while even at 6 inches below the surface the temperature is much higher in the instance of fired soils. During the night - especially during the coldest months - the temperature of the surface is frequently several degrees lower upon fired than upon plant-clad soils. E.P. Phillips (1920A) has investigated the temperature conditions upon fired and covered soils in the Climax Grassland, Pretoria, while in connection with the ecology of the Tsetse-fly, my colleagues and myself have for some time been engaged in a thorough comparison of the temperature and allied factors upon fired and fully protected soils in the Tree-and-Grass Savanna of East Africa. Fries (1921: 92), on the basis of several thermometric readings at $5 \mathrm{~cm}$ and $12 \mathrm{~cm}$ within fired and nonfired soils in Berlinia Brachystegia-Other Species Woodland-Trockenwald of En- 
gler-in Northern Rhodesia, attributes the earlier development of green growth in fired soils to the increased temperature in early spring. My observations in Tanganyika go to support this view. From studies in the Knysna region I should say, too, that green growth appearing more rapidly in the late winter and early spring, upon fired Macchia soil than upon undisturbed sites adjacent, is to a large extent the outcome of the increased soil temperatures. In this region, however, soil-moisture differences, too, have to be taken into account.

A point of importance with respect to temperature and firing is that in regions where frost does not occur-for example, in most parts of the tropics of East Afri$\mathrm{ca}$ - the grass fires are not so fierce as they are in grass of equal luxuriance in regions like Southern Rhodesia and South Africa where frost kills back the greater portion of the growth above ground.

(vii) There is scarcely need to refer to the general physiographical, physical, chemical, and biological changes, collectively known as soil erosion, that take place upon soils from which the vegetation has been removed by fire. Such exposed sites, under the action primarily of increased insolation, increased rate of wind-flow, and accelerated and augmented rate of "run-off" of rainwater, rapidly show either vertical "gully" or horizontal "sheet" erosion. The literature is filled with references to the influences of fire in increasing erosion, while every observant practical man is able to testify to the evil effects of continued firing upon sites susceptible to erosion. From personal observations in South and East Africa I hold that the nature and the rate of erosion and of the complementary process of deposit of wind and water borne detritus, entirely depends upon the manner in which the following features are integrated: (a) climatic zone,

(b) local physiography,

(c) soil type,

(d) vegetation community,

(e) season of firing as related to season of rainfall,

(f) nature and periodicity of rainfall,

(g) the strength and periodicity of wind,

(h) nature and rate of evaporation from the soil surface.

This aspect I mention, as I desire to emphasize the need for our obtaining basic regional information before we decide upon regional fire policies.

(viii) As in many instances soil erosion is the outcome of continuous firing, it is but natural that the hydrographical conditions of a countryside should, pari passu, be effected for the worse. Indeed, this is all too frequently exemplified in forest regions in South and East Africa - a steady but sure reduction in stream-flow and an increased desiccation following years of severe firing. In this special connection, I am convinced from observations made in the subtropics and the tropics, that complete protection from fire of the summits and slopes of uplands must be put into effect through education of the European public and the native, and by legislation supported by adequate measures to ensure carrying out of the regulations. Loss by vegetation from water-catchment-areas not only means that the natural vegetation sponge necessary for the absorption and conservation of water is removed, but also that the cooling surface supplied by the plants, and of such definite use in the condensation of hydrometeoric mists, (vide Phillips 1928A) is lost.

(ix) From a few atmometric (LivingstonThone non-absorbent spherical cup atmometers) measurements taken by myself 
in the Knysna region of South Africa, and from a much more detailed series of readings being taken in various communities in Tanganyika Territory by my colleagues and myself, it is plain that removal of even short herbage and grass is responsible for increased evaporating power of the air. Undoubtedly this increase in aridity is due to the increased temperature and the decreased humidity of the air above the black, heat-absorbing ground, and to the accelerated rate of air-flow.

(x) In the Savannas of East Africa the proportion of direct sunlight is much decreased during the months May-October, for during these months the skies are for appreciable periods overcast by dun palls of smoke arising from the great fires that sweep the country from end to end. It is interesting to note that Brown (1887) records a fire in the Southwestern Cape that caused a smoke pall 120 miles long by 7 to 8 miles wide, to hang over the country for some days.

\section{SUGGESTIONS REGARDING FUTURE INVESTIGATIONS}

Several times I have hinted that we require fuller, more detailed information regarding the influences of fire upon vegetation, animals, and habitat factors. I wish to sketch the major lines along which I consider we should proceed with dynamic investigations:

(i) Within the main types of vegetation (for example Forest, Macchia, Karroo, Climax Grassland, seral Tree-and-Grass Savanna) and within the larger subclimate zones and soil types within these, we should execute observational and quadrat studies regarding the influences of fire upon the plantand-animal communities.

(ii) Arising from information yielded by such observational and quadrat studies, we should conduct carefully planned experimental work; on the basis of enclosures, exclosures, whole and partial protection from fire and from fire and animals for varying periods, and seasonal fires.

(iii) In the foregoing investigations it is essential that thorough measurement of the primary and secondary edaphic and aerial factors of the habitat should be arranged. To my mind of great importance are

(a) the water-supplying-power of the soil,

(b) the maximum-water-retaining capacity of the soil,

(c) the available-water-content of the soil,

(d) the air capacity, and the rate of airflow in the soil,

(e) the permeability of the soil,

(f) the hydrogen-ion concentration of the soil solution,

(g) the total soluble salts readily available to plants,

(h) the evaporating power of the air,

(i) the rate of wind-flow,

(j) the degree of "run-off" of rainwater.

(iv) We should accumulate properly integrated data bearing upon plant-indicators, these indicators being of real utility when we have to decide upon the "fire-history" of sites, and have to suggest lines of future "fire management." Information of a general character bearing on this subject appears in various places in the writings of Bews, while a beginning in this connection was made by myself (Phillips 1928B: 220) in the Knysna region.

In a word, by intensive and extensive methods, and in accordance with a carefully planned, dynamic programme we should collect information bearing upon those matters of such vital economic importance as whether to burn, what to burn, when to burn, how to burn. 
The knowledge obtained should be applied experimentally upon a scale sufficiently large to preclude purely local extremes from seriously affecting the results.

\section{SUMMARY OF INFLUENCES}

Volkens (1897: 266), Wisslnann (1888) and Reichard who travelled in East Africa considered that fire did little harm; Reichard ( $p$. 46) went so far as to say it was one of the benefits of the year. Schweinfurth (1874), Pechuel-Loesche (1887), Bornhardt (1900), and almost all South African writers find no merit whatever in the firing of vegetation. The Drought Investigation Commission (1926), for example, "unequivocally states that veld burning is contrary to the interests of the country as well as to the principles of all veld and soil conservation..." (italics mine).

On the other hand, Busse (1908), Bews (1918, 1929: 347), and Staples (1926) realise that controlled firing of grassland has its useful features. With this view I am in cordial agreement. No one who has studied experimentally or by means of quadrats the responses of different types of vegetation to firing in definite seasons, can fail to look upon controlled firing as a useful and necessary agency for the keeping in position of particular stages of the biotic succession. Thus, in regions where the development is toward either Scrub or Forest, valuable grazing would be lost were firing withheld completely: tall, coarse grass, shrubs and trees would oust the grasses and herbs so suitable for grazing. It is to be remembered that the greater portion of the Eastern Grassveld of Bews (1918), and much of Southern and Northern Rhodesia, Nyassaland, Tanganyika, Uganda, and Kenya, would develop to denser vegetation were firing with-held. An interesting example of the useful influences of fire exists in Schonland's (1927) prescription for the firing of Helichrysum argyrophyllum that has developed as the result of overgrazing seral grassland in the Amatola mountains.
I have already touched upon the seeming utility of controlled firing in the Tsetse-fly problem, the degree of utility depending upon climatic, soil, and vegetational conditions. On reviewing what is known of the influences of firing in South and East Africa, I feel it desirable to urge the need of our carefully considering all regional circumstances in the light of scientific experience, before we definitely decry the practice of firing. Possibly I may be criticised for this statement, but in making it I consider I have but done my duty.

\section{SUMMARY}

In South and East Africa the influences of the age-old practice of firing vegetation are of the first biological and economic importance. Despite the popular interest exhibited in the effects of burning vegetation, our scientific information requires augmenting considerably.

An attempt is made to outline the more important, more easily discernible changes in the vegetation following firing, in

(i) Climax Grassland,

(ii) Tree-and-Grass Savanna developing to either Deciduous or Evergreen Scrub Climaxes,

(iii) Macchia or "Fijnbosch,"

(iv) Subtropical and Tropical Evergreen Forest.

That vast stretches of Southern and Eastern Africa have their vegetation kept in an "open" or non-climax condition, by annual and periodic fires, seems plain from the evidence upon the ground.

It is held that fire in the Tree-and-Grass Savannas has played no little part in the development of certain growth-forms in plants.

Firing in the Savanna regions profoundly affects the behaviour of the animals associated with the vegetation.

From the relatively small amount of intensive work that has been accomplished, no mat- 
ter what portion of the world is considered, it seems that firing, according to climatic, soil and vegetational conditions obtaining within a region, brings about changes of far-reaching consequence in the physical, chemical and biological conditions in soils.

Suggestions regarding probable fruitful lines for future research include quadrat and experimental studies in various climatic, soil and vegetational types, investigation of certain fundamentally important soil characteristics, collection of data upon "fire" plant-indicators, and application of all information won to practical problems in vegetation management.

In reviewing the state of our knowledge as to the influences of firing, it is held that neither those who consider firing as having no evil effects nor yet those who state it to have no merits are correct. Controlled firing is a useful and oftentimes necessary agent in veld management and in Tsetse-fly control. It is urged that generalisations regarding the influences of firing should be made only after the local circumstances have been examined.

\section{REFERENCES}

Bews, J.W. 1918. The grasses and grasslands of South Africa.

Bews, J.W. 1925. Plant forms and their evolution in South Africa.

Bews, J.W. 1927. Studies in the ecological evolution of the angiosperms. New Phytologist: reprint 16.

Bews, J.W. 1929. The world's grasses.

Bornhardt, W. 1900. Zur Oberflachengestaltung und Geologie Deutsch-Ostafrikas. [DeutschOst-Afrika 7, 595 S. Dietrich Reimer] Berlin, [Germany. In German].

Botha, C.G. 1924. Note on early burning in the Cape Colony. South African Journal of Science 21: 351-352.

Brown, J.C. 1887. Management of crown forests at the Cape.

Busse, W. 1908. Die periodischen Grasbrände im tropischen Afrika, ihr Einfluss auf die Vegetation und ihre Bedeutung für die Landeskultur. Mitteilungen aus den Deutschen Schutzgebieten 21, Heft 2. [In German.]

Clements, F.E. 1916. Plant succession. Publication 242, Carnegie Institute of Washington, [D. C., USA. doi: 10.5962/bhl.title.56234]

Compton, R.H. 1929. The results of veld-burning. Bulletin, Department of Education, Cape of Good Hope, [South Africa].

Drought Investigation Commission. 1926. The great drought problem of South Africa. Journal of the Department of Agriculture: Reprint 16. (Vide also the full report.)

Eden, T. 1924. The edaphic factors accompanying the succession after burning on Harpenden Common. Journal of Ecology 12(2): 267-286. [doi: 10.2307/2255250]

Fries, R.E. 1921. Wissenschaftliche Ergebnisse der Schwedischen Rhodesia-Kongo-Expedition 1911-12 Unter Leitung von Eric Graf von Rosen. Botanische Untersuchungen Ergänzungsheft, Band I. [In German.]

Gibbs, L.E. 1906. A contribution to the botany of southern Rhodesia. Botanical Journal of the Linnaen Society 37: 425-494. [doi: 10.1111/j.1095-8339.1906.tb00846.x]

Harison, C. 1856-1874. Manuscript reports for forests of Alexandria and King Williams Town. [Department of Agriculture, Forest Department, Cape Town, South Africa.]

Harison, C. 1856-1888. Manuscript reports for forests of Knysna, George, and Humansdorp. [Department of Agriculture, Forest Department, Cape Town, South Africa.]

Harran, P.C. 1898. Report of the District Forest Officer, Keiskama Hoek. [Department of Agriculture, Forest Department, Cape Town, South Africa.] 
Henkel, C.C. 1889. Report of the Conservator of Forests, Transkei. [Department of Agriculture, Forest Department, Cape Town, South Africa.]

Henkel, J.S. 1928. The relation of vegetation to water supply in southern Rhodesia. South African Journal of Science 25: 38-51.

Hutchins, D.E. 1884. Report of the Conservator of Forests, Eastern. [Department of Agriculture, Forest Department, Cape Town, South Africa.]

Hutchins, D.E. 1909. Report on the forests of British East Africa. Her Majesty's Stationery Office, [United Kingdom].

Jaeger, F. 1911. Das Hochland der Riesenkrater. Mitteilungen aus den Deutschen Schutzgebieten Ergänzungsheft 5. [In German.]

Kolbe, P. 1727. Beschrijving van de Kaap de Goede Hoop. [In Dutch.]

Levyns, M.R. 1922. Some observations on the effects of a bush fire on the vegetation of Signal Hill. Transactions of the Royal Society of South Africa 10(4).

Levyns, M.R. 1924. Some observations on the effects of bush fires on the vegetation of the Cape Peninsula. South African Journal of Science 21: 346-347.

Levyns, M.R. 1929A. Veld burning experiments at Ida's Valley, Stellenbosch. Transactions of the Royal Society of South Africa 17(2): 61-91. [doi: 10.1080/00359192909518772]

Levyns, M.R. 1929B. The problem of the Rhenoster Bush. South African Journal of Science 26: 166-169.

Lieder, [G]. 1897. [Reise von der Mbampa-Bai am Nyassa-See nach Kisswere am Indischen Ozean.] Mitteilungen aus den Deutschen Schutzgebieten 10: 95-142. [In German.]

Lister, J.S. 1889. Report of the Conservator of Forests, Eastern. [Department of Agriculture, Forest Department, Cape Town, South Africa.]

Marloth, R. 1924. Notes on the question of veld burning. South African Journal of Science 21: 342-345.

Meyer, H. 1892. Der Kilimandscharo. Leipzig, [Germany. In German.]

Obst, E. 1923. Das abflusslose Rumfschollenland im nordöstlichen Deutsch-Ostafrika. Teil II. Mitteilungen der Geographischen Gesellschaft in Hamburg: 35. [In German.]

Pappe, L. 1862. Silva Capensis. Second edition. [Van de Sandt de Villiers,] Cape Town, [Africa].

Pardy, A. 1906. Grass-burning. Natal Agriculture Journal 9(7):686-687.

Pechuel-Loesche, E. 1887. Kongoland. [H. Costenoble,] Jena, [Germany. In German.]

Phillips, E.P. 1920A. A preliminary report on the veld-burning experiments at Groenkloof, Pretoria. South African Journal of Science 16: 285-299.

Phillips, E.P. 1920B. Veld burning experiments at Groenkloof: second report. Science Bulletin 17, Department of Agriculture, South Africa.

Phillips, J.F.V. 1926. Succession and climaxes in the Knysna region. Carnegie Institute of Washington Year Book 25: 365-367.

Phillips, J.F.V. 1928A. The influence of forest formation upon soil moisture. Nature [122: 5354. doi: 10.1038/122053a0]

Phillips, J.F.V. 1928B. Plant indicators in the Knysna region. South African Journal of Science 25: 202-224.

Phillips, J.F.V. 1930A. The biotic community. [Presented at the Fifth] International Botanical Congress, Cambridge, [United Kingdom. 16-23 August 1930.] [Journal of Ecology 19: 1-24.]

Phillips, J.F.V. 1930B. Forest succession and ecology in the Knysna region. [Issue 14,] Memoirs of the Botanical Survey of the Union of South Africa. 
Pillans, N.S. 1924. Destruction of indigenous vegetation by burning on the Cape Peninsula. South African Journal of Science 21: 348-350.

Reichard, P. No date. Deutsch-Ostafrika.

Sander, [L., and Hennig.] 1906. [Tropische und subtropische Viehseuchen. Pages 689-780 in: C.] Mense, [editor.] Handbuch der Tropenkrankheiten, volume III. [J.A. Barth, Leipzig, Germany. In German.]

Schonland, S. 1927. On the reclamation of ruined pasturage on the Amatolas, near Keiskama Hoek. Science Bulletin 55, Department of Agriculture, [South Africa.]

Schweinfurth, [G.] 1874. In Herzen von Afrika. Teil 1. [F.A. Brockhaus, Leipzig, Germany. In German.]

Siebenlist, T. 1914. Forstwirtschaft in Deutsch-Ostafrika. Berlin, [Germany. In German.]

Sim, T.R. 1900. Botanical observations on forests of eastern Pondoland. Agricultural Journal of the Cape of Good Hope 16: 21-33.

Sim, T.R. 1907. The forests and forest flora of Cape Colony.

Staples, R.R. 1926. Experiments in veld management: first report. Science Bulletin 49, Department of Agriculture, South Africa.

Stead, A. 1912. The use of wood ashes for manurial purposes. South African Journal of Science 9: 66-67.

Swynnerton, C.F.M. 1921. Bulletin of Entomological Research 11(4): 315-385. [doi: 10.1017/ S0007485300044746]

Tansley, A.G., and T.F. Chipp. 1926. Aims and methods in the study of vegetation. [British Empire Vegetation Committee and the] Crown Agents for the Colonies, [London, United Kingdom.]

Troup, R.S. 1922. Report on forestry in Kenya Colony. Crown Agents for the Colonies, [London, United Kingdom. doi: 10.5962/bhl.title.22936]

Wissmann, H. 1888. Im Innern Afrikas. Leipzig, [Germany. In German.].

Volkens, G. 1897. Fer Kilimandscharo. Berlin, [Germany. In German.] 